\title{
Human Resources Practices in Effective Corporate Governance Approach
}

\author{
Murat Çolak \\ Associate Professor \\ Faculty of Economics and Administrative Sciences \\ Dokuz Eylul University, İzmir, Turkey \\ E-mail: colak@muratcolak.com \\ Melce Elegel \\ Human Resources Specialist, İzmir, Turkey \\ E-mail: melce_elegel@hotmail.com
}

Received: July 19, 2020 Accepted: August 11, 2020 Online published: August 28, 2020

doi:10.5296/ijhrs.v10i3.17596ＵRL: https://doi.org/10.5296/ijhrs.v10i3.17596

\begin{abstract}
Corporate governance is a concept that emphasizes sustainable growth and stability in order to successfully transfer businesses to future generations. It also allows businesses to be well managed under a professional, transparent, fair and accountable management approach. Corporate governance is closely related to the human resources practices carried out by the businesses and the institutionalization levels of the businesses. The lack of any initiative on human resources practices in enterprises or the lack of these practices constitutes the biggest obstacle to the institutionalization of businesses. The study created for this purpose is structured to examine the impact of human resources practices on corporate governance understanding. The study sample was prepared in a business in the food and beverage industry with 66 branches operating in Turkey. Qualitative research method based on the interview, document review and observation techniques was applied. According to the findings, successful human resource management practices were found to be closely related to the levels of corporate governance and institutionalization. It was determined that the deficiencies in human resources practices on the researched business prevented the formation of institutionalization and then prevented the corporate governance understanding.
\end{abstract}

Keywords: institutionalization, corporate governance and human resources practices 


\section{Introduction}

Today, businesses need human resources management to maintain sustainable growth and competition. With this need, significant tasks and responsibilities fall to the human resources departments of the businesses. The most important duty and responsibility of human resources departments is to ensure full and effective execution of human resources practices. At this point, it is inevitable that the businesses that adopt human resources practices and carry out these practices in a just manner as they should be, will succeed and be sustainable. Besides, the full and effective execution of human resources practices enables business management to be independent of individuals, in other words, the institutionalization of businesses. Businesses that have completed the institutionalization process effectively with the impact of human resources practices also bring about the corporate governance approach.

Basically, corporate governance is defined as the concept that enables controlling all processes of the business and conducting successful business-specific policies. It enables businesses to be managed within the framework of certain principles, to base internal and external customer relations on certain rules, to meet goals and objectives on a common ground. System-oriented structuring of corporate governance independent of individuals interacts with human resources practices. Therefore, the importance of this concept is gradually increasing. Indeed, the need to strategically manage corporate identity is an indicator of this.

As in any management approach, the corporate governance approach is also based on human beings. However, the corporate governance approach is a system-oriented approach independent of individuals. This reveals the necessity of meticulously managing all the work to be done on corporate governance. At this point, human resources practices and corporate governance approach emerge as two important issues that affect each other and to be affected with each other. In short, if an effective corporate governance approach is desired, human resources practices should not be ignored.

\section{Theoretical and Conceptual Background}

\subsection{Institutionalization}

Institutionalization is a holistic structure involving the processes by which social processes, obligations or actualities come to take on a rule-like status in social thought and action (Meyer \& Rowan, 1977, p. 341). Perhaps the most important meaning of the concept of institutionalization is that it expresses a value (in other words, it has the value) beyond the technical knowledge required by the work. In order to maintain this value, businesses must constantly expend energy in order not to break away from the rational, technical, non-individualistic system against all negative pressures that may come from the environment (Selznick, 1957, p. 17).

It is seen that it is possible to carry out business activities within a system, to ensure integrity between employees and business objectives, to gain sustainability of the business asset through institutionalization (Colyvas \& Powell, 2006; Lawrence et al., 2001). However, the realization of institutionalization and the firm's progress in the future depends on several 
factors. These elements are formalization, professionalization, autonomy, culture, consistency, transparency and social responsibility.

The higher the number of written documents and the confidence in these documents, the higher the level of formalization of the business (Hodge et al., 2003, p. 38). What is expected in businesses with a high level of formalization is the realization of professionalization. Professionalization creates a management style that integrates professional employees and their functions within the enterprise (Barnes \& Hershons, 1976, pp. 106-110; Bresnen, 2013). Professionalization is based on internalized standards, expertise, and knowledge to control behavior rather than favoring bureaucratic or administrative mechanisms (Ganesh \& McAllum, 2012; Hrebiniak, 1976, p. 664).

Autonomy, the degree of ability to make important decisions, is the ability to make important decisions about the work of a manager or another employee on the subject without the permission of other individuals (Brock, 2003, p. 58; Wallace, 1995, p. 231). Therefore, it is formed through the working culture that exists within the business (Çolak, 2018, p. 46; Harris \& Hartman, 2001, p. 75; Mihalache \& Albu, 2016, p. 149). A strong foundation for businesses is also formed by consistent and transparent policies (Bandsuch et al., 2008, pp. 110-111; Denison, 1990, p. 6; Tawney, 1907, p. 21). Social responsibility, which is characterized as an ethical concept in the organizational context, also constitutes an important element of institutionalization in terms of the impact of the activities carried out by the business on the society (Fisher, 2004, p. 392).

Each stage of the institutionalization process is important because it brings about institutionalization. At this point, all the work to be done for each stage must be carried out meticulously. In this way, as more stability and social integration are achieved in the business, the business becomes a valued structure beyond being a tool to achieve its goals (Broom \& Selznick, 1975, p. 233; Kansikas, 2010, p. 33; Leuthesser \& Kohli, 1997; Olins, 1990, p. 7).

\subsection{Corporate Management and Human Resources Practices}

Corporate governance is a concept related to the use of power over corporate assets. As important developments regarding the concept were recorded in the 20th century, today it has become one of the main issues in the regulation of modern business (Tricker, 2009, p. 7). It contains the rules and norms that regulate the internal relations between various stakeholders, including owners, directors, managers, creditors, suppliers, employees and customers in businesses (Pauly \& Reich, 1997, p. 8). The rules, relations, systems and processes that supervisory authority is applied and controlled in businesses are the basis of corporate governance (Belloc, 2012; Lane, 2003, p. 80).

Corporate governance allows the relationships between internal and external customers (in other words, relationships between all stakeholders) to be managed within the framework of universally accepted principles of transparency, fairness, accountability and responsibility. (Bushman et al., 2004, p. 207; Curtin \& Meijer, 2006, p. 111; Doğan, 2007, p. 54; Erkan, 2012, p. 72; Shearer, 2002, p. 545). However, establishing a strong and effective corporate governance structure in businesses is a time consuming and laborious process. Therefore, it 
seems unlikely that this structure will be created in a short time (Anand, 2007, p. 133).

The concept of corporate governance, which sets the ground for long-term and sustainable value creation in enterprises (Monks \& Minow, 2008, p. 2), is interacted with human resources practices. In addition to reaching the professional managers needed in businesses, the provision of services to support the achievement of corporate objectives, creating an environment where productive and harmonious relations between management and employees can be maintained and mutual trust can be developed, managing internal and external stakeholders (Konzelmann et al., 2007) taking into account individual and group differences, providing equal opportunities accessible to all are possible with effective management of human resources practices. It also allows the successful management of the relations between all stakeholders of a business, including society, the state, business owners, management, employees, customers and suppliers in general. At this point, corporate governance emerges as a concept that emphasizes the management of internal and external stakeholders (Armstrong, 1999, pp. 3-4). As a result, effective management of human resources practices prepares the ground for adopting an ethical approach that gives importance to transparency, fairness, accountability and responsibility, that is, creating a corporate governance approach (Athmen \& Samia, 2017; Beatty et al., 2003; Ibrahim and Zulkafli, 2016; Konzelmann et al., 2006; Martin and Gollan 2012; Martin et al., 2016; Nyambegera, 2017; Supangco, 2006).

As can be seen, the formation of an effective corporate governance approach depends primarily on human resources and therefore on the implementation of human resources practices in an appropriate manner and in accordance with its purpose. Human resources practices allow the business to influence employee skills through the acquisition and development of human capital (Huselid, 1995, p. 637), while at the same time providing the basis for fair management of the business. In this regard, considering the fact that each input of human resources applications will be the output of another application, the first thing to be done in the business is the need for conducting the work analysis work meticulously. The outputs obtained as a result of job analysis will be the inputs of recruitment and placement, training and development, performance management and evaluation, career and wage management. In other words, business analysis outputs will form a basis for the mentioned human resources practices and will affect their success. Besides, with the human resources applications carried out with due care, businesses will take important steps towards institutionalization and this will bring an understanding of corporate governance. For this reason, it can be said that corporate management and human resources practices interact and that human resources practices play a complementary and strategic role in the formation of an effective corporate management approach.

\section{Method}

\subsection{Data and Sample}

In this research, in which the qualitative research method was used, the sample was determined according to the purposeful sampling method. In this respect, the sample includes twelve department managers working in different departments of a business operating in the food and beverage sector in Izmir, Turkey. The qualitative data obtained from the relevant 
sample between 20.12.2017 when the interviews started and 19.06.2018 when the interviews ended constitute the limitation of the research.

\subsection{Analyses}

The main hypothesis of the research is structured as "The lack of a human resources department in businesses and the deficiencies in human resources practices affect the institutionalization and subsequently corporate governance approach". In this context, the audio recordings made during the interview were translated into the text just before the analysis of the data obtained from the sample determined for the study. The records converted to the text were separated on the basis of departments and the coding process was carried out in order to keep the name of the employees interviewed in these departments confidential. After the coding process was done, the audio recordings were transferred to the text along with the notes taken during the interview and made ready for analysis. Therefore, the qualitative data obtained from the relevant sample were evaluated using the descriptive analysis method.

\subsection{Measures}

The data were collected by using a semi-structured interview, document review method and observation method. The information that the data collected during the interviews would be used only within the scope of this study within the framework of ethical values was given to both senior management and the employees involved in the interview.

In this business, which does not have a human resources department, the following 6 basic questions were asked to the Department officers:

1. Which department or manager are you working with?

2. How many people are there in your team or department?

3. Do you report to senior management?

4. What are the processes you want to change?

5. What do you think about your duties and responsibilities?

6. What are the problems you observe throughout the business?

General information about the persons and their titles, dates and times of the interviews are summarized in the table below.

Table 1. Descriptive Information about the Departments and Employees Interviewed

\begin{tabular}{|c|c|c|c|c|c|c|}
\hline $\begin{array}{c}\text { Department } \\
\text { Interviewed }\end{array}$ & Interviewee & Gender & $\begin{array}{c}\text { Marital } \\
\text { Status }\end{array}$ & $\begin{array}{l}\text { Interview } \\
\text { Date }\end{array}$ & $\begin{array}{l}\text { Interview } \\
\text { Time }\end{array}$ & Position \\
\hline $\begin{array}{c}\text { Senior } \\
\text { management }\end{array}$ & E1 & Male & Married & 20.12 .2017 & $09: 00$ & $\begin{array}{c}\text { Deputy } \\
\text { Director } \\
\text { General }\end{array}$ \\
\hline $\begin{array}{c}\text { Senior } \\
\text { management }\end{array}$ & K1 & Female & Single & 27.12 .2017 & $15: 00$ & $\begin{array}{c}\text { Project } \\
\text { Manager }\end{array}$ \\
\hline $\begin{array}{c}\text { Senior } \\
\text { management }\end{array}$ & E2 & Male & Married & 27.12 .2017 & $16: 00$ & $\begin{array}{c}\text { Accounting } \\
\text { Manager }\end{array}$ \\
\hline $\begin{array}{c}\text { Business } \\
\text { Development }\end{array}$ & K2 & Female & Single & $\begin{array}{c}19.02 .2018 \\
17.05 .2018\end{array}$ & $\begin{array}{c}16: 00 \\
17: 40\end{array}$ & $\begin{array}{c}\text { Business } \\
\text { Development }\end{array}$ \\
\hline
\end{tabular}




\section{Macrothink}

International Journal of Human Resource Studies

ISSN 2162-3058

2020, Vol. 10, No. 3

\begin{tabular}{|c|c|c|c|c|c|c|}
\hline Department & & & & 12.06 .2018 & $15: 30$ & Manager \\
\hline $\begin{array}{l}\text { Purchasing } \\
\text { Department }\end{array}$ & K3 & Female & Married & $\begin{array}{l}27.02 .2018 \\
16.03 .2018 \\
27.03 .2018\end{array}$ & $\begin{array}{l}10: 30 \\
12: 30 \\
09: 30 \\
\end{array}$ & $\begin{array}{l}\text { Purchasing } \\
\text { Manager }\end{array}$ \\
\hline Help Desk & K4 & Female & Married & $\begin{array}{l}27.02 .2018 \\
06.04 .2018\end{array}$ & $\begin{array}{l}11: 30 \\
14: 10\end{array}$ & Personnel \\
\hline $\begin{array}{l}\text { Finance and } \\
\text { Accounting } \\
\text { Department }\end{array}$ & K5 & Female & Married & $\begin{array}{l}30.03 .2018 \\
26.04 .2018 \\
18.05 .2018 \\
\end{array}$ & $\begin{array}{l}15: 00 \\
19: 05 \\
15: 50 \\
\end{array}$ & $\begin{array}{c}\text { Accounting } \\
\text { Manager }\end{array}$ \\
\hline $\begin{array}{c}\text { Investor } \\
\text { Relations and } \\
\text { Audit } \\
\text { Department }\end{array}$ & E3 & Male & Married & $\begin{array}{l}09.04 .2018 \\
19.06 .2018\end{array}$ & $\begin{array}{l}\text { 09:45 } \\
\text { 10:00 }\end{array}$ & $\begin{array}{l}\text { Operations } \\
\text { Manager }\end{array}$ \\
\hline $\begin{array}{l}\text { Advertising } \\
\text { and Agency } \\
\text { Department }\end{array}$ & E4 & Male & Married & 22.05 .2018 & 16:00 & Art Director \\
\hline $\begin{array}{l}\text { Finance and } \\
\text { Accounting } \\
\text { Department }\end{array}$ & E5 & Male & Married & 18.05 .2018 & $15: 50$ & $\begin{array}{c}\text { Chief } \\
\text { Accounting } \\
\text { Officer }\end{array}$ \\
\hline $\begin{array}{l}\text { Purchasing } \\
\text { Department }\end{array}$ & E6 & Male & Married & 27.02.2018 & 11:00 & $\begin{array}{c}\text { Warehouse } \\
\text { Manager }\end{array}$ \\
\hline $\begin{array}{l}\text { Architecture } \\
\text { Department }\end{array}$ & K6 & Female & Single & $\begin{array}{l}30.05 .2018 \\
12.06 .2018\end{array}$ & $\begin{array}{l}\text { 09:30 } \\
17: 00\end{array}$ & Architect \\
\hline
\end{tabular}

\section{Results}

A number of questions were posed to the relevant sampling in order to highlight the main problems faced by employees related to human resources practices, institutionalization and corporate governance in the enterprise included in the research. All details regarding these questions and their answers are as follows.

Table 2. Which department or manager are you working with?

\begin{tabular}{|l|l|l|}
\hline Position & Interviewee & Answer to the Question \\
\hline $\begin{array}{l}\text { Business } \\
\text { Development } \\
\text { Manager }\end{array}$ & $\mathrm{K} 2$ & $\begin{array}{l}\text { "The department we are in is not } \\
\text { affiliated with a unit or person" }\end{array}$ \\
\hline $\begin{array}{l}\text { Purchasing } \\
\text { Manager }\end{array}$ & $\mathrm{K} 3$ & $\begin{array}{l}\text { "As a purchasing department, we } \\
\text { work under a manager." }\end{array}$ \\
\hline $\begin{array}{l}\text { Help Desk } \\
\text { Personnel }\end{array}$ & $\mathrm{K} 4$ & $\begin{array}{l}\text { "I do not know. I'm mostly in contact } \\
\text { with the Deputy General Manager." }\end{array}$ \\
\hline $\begin{array}{l}\text { Operations } \\
\text { Manager }\end{array}$ & $\mathrm{E} 3$ & $\begin{array}{l}\text { "We work under the Deputy General } \\
\text { Manager" }\end{array}$ \\
\hline Art Director & $\mathrm{E} 4$ & $\begin{array}{l}\text { "Although we seem to be connected } \\
\text { to senior management as a a } \\
\text { department, I can say that we are an } \\
\text { independent department as a } \\
\text { functioning and business." }\end{array}$ \\
\hline
\end{tabular}


As a result of the responses to this question addressed to the department officers, it was revealed that the Business Development Department didn't have a manager or supervisor to which it was affiliated, the Help Desk department didn't know the manager to which it was affiliated and Purchasing, Finance and Accounting, and Operation Departments had managers. The Advertising and Agency Department emphasized that they were affiliated with the senior management, but they were an independent department in operation. All responses to the question of "Which department or manager are you working with?" indicate that the business is experiencing problems in a hierarchical sense.

Table 3. How many people are there in your team or department?

\begin{tabular}{|l|l|l|}
\hline Position & Interviewee & Answer to the Question \\
\hline $\begin{array}{l}\text { Purchasing } \\
\text { Manager }\end{array}$ & $\mathrm{K} 3$ & $\begin{array}{l}\text { "We are 4 guys here. In dry } \\
\text { warehouse processes are carried } \\
\text { out by two people while in frozen } \\
\text { warehouse processes are carried } \\
\text { out by one person " }\end{array}$ \\
\hline $\begin{array}{l}\text { Help Desk } \\
\text { Personnel }\end{array}$ & $\mathrm{K} 4$ & $\begin{array}{l}\text { "We had another friend at the } \\
\text { Help Desk before. He left. I'm } \\
\text { currently working alone. " }\end{array}$ \\
\hline $\begin{array}{l}\text { Operations } \\
\text { Manager }\end{array}$ & $\mathrm{E} 3$ & $\begin{array}{l}\text { "The operation process is } \\
\text { carried out by four people." }\end{array}$ \\
\hline $\begin{array}{l}\text { Art } \\
\text { Director }\end{array}$ & $\mathrm{E} 4$ & $\begin{array}{l}\text { "With the logic of } \\
\text { semi-department, semi-agency, } \\
\text { our work is carried out by 4 } \\
\text { people in this department, } \\
\text { including me." }\end{array}$ \\
\hline
\end{tabular}

The question of "How many people are there in your team or department?" was addressed to the Department officers and answers were received. Accordingly, it was observed that the number of employees in the departments was insufficient.

Table 4. Do you report to senior management?

\begin{tabular}{|l|l|l|}
\hline Position & Interviewee & Answer to the Question \\
\hline $\begin{array}{l}\text { Purchasing } \\
\text { Manager }\end{array}$ & $\mathrm{K} 3$ & $\begin{array}{l}\text { "We don't do reporting. Maybe not in the } \\
\text { sense of a report, but I have tables that I } \\
\text { have created for myself. I pass this on to } \\
\text { senior management from time to time." }\end{array}$ \\
\hline $\begin{array}{l}\text { Help Desk } \\
\text { Personnel }\end{array}$ & $\mathrm{K} 4$ & $\begin{array}{l}\text { "There are no reports I prepared regularly. I } \\
\text { prepare the report on demand" }\end{array}$ \\
\hline
\end{tabular}

Business Development, Finance and Accounting, Operations, Advertising and Agency and Architecture Departments answered the question of "Do you report to senior management?" by saying "No". In addition to the response stated in the Table, the employee with the code 
K3 also emphasized the importance of reporting for the Purchasing Department by saying "Reporting on tonnage and price can be obtained routinely from the Netsis program used. In this way, it is possible to see the operating performance easily." The responses to the questions revealed that in some departments, reporting was done on demand and from time to time, while in some departments it was not done at all. The K3 code employee who serves as the purchasing officer in the purchasing department emphasizes that reporting makes critical information visible to the business. For this reason, the necessity and importance of routine reporting of the Business Development and Purchasing Department in order for the top management to be informed about the operation is reflected in the discussions.

Table 5. What are the processes you want to change?

\begin{tabular}{|c|c|c|}
\hline Position & Interviewee & Answer to the Question \\
\hline $\begin{array}{l}\text { Accounting } \\
\text { Manager }\end{array}$ & K5 & $\begin{array}{l}\text { "The Finance and Accounting Department does not work without } \\
\text { authorization or approval. We are conducting existing works with } \\
\text { or without manager, but we do not want to take action without } \\
\text { approval." "Those who know the institution much better in terms of } \\
\text { managing, directing and empowering, rather than responsibility in } \\
\text { terms of workload, need to take responsibility." } \\
\text { "Accounting should not take the risk of products leaving the } \\
\text { warehouse." }\end{array}$ \\
\hline $\begin{array}{l}\text { Help Desk } \\
\text { Personnel }\end{array}$ & K4 & $\begin{array}{l}\text { "The Purchasing Department needs to inform me about which } \\
\text { product it sends. However, there are problems with this. Especially } \\
\text { during the periods of menu transitions, the Purchasing Department } \\
\text { is unable to plan their working order due to the intensity. I'm being } \\
\text { negatively affected by this." }\end{array}$ \\
\hline $\begin{array}{l}\text { Operations } \\
\text { Manager }\end{array}$ & E3 & $\begin{array}{l}\text { "We're too busy with paperwork in the office so we can't be as } \\
\text { active on the field as we would like. In the department, we're } \\
\text { actually short in numbers. A new employee can be integrated into } \\
\text { the office. If there is such an employee, the reporting of those done } \\
\text { in the field and all paperwork are provided by this employee. We'll } \\
\text { be more active in the field." }\end{array}$ \\
\hline Art Director & E4 & $\begin{array}{l}\text { "It is our most planned and institutional employee department. In } \\
\text { order to ensure that we can proceed in a planned way, information } \\
\text { about the menus must come to us in advance. However, the } \\
\text { processes resulting from the lack of information about menus are } \\
\text { progressing unplanned. Despite this, there have been no jobs that } \\
\text { haven't been done in time. Unfortunately, we had to compromise on } \\
\text { the design in order to finish the work at the given time." }\end{array}$ \\
\hline Architect & K6 & $\begin{array}{l}\text { "We spend } 80 \%, 90 \% \text { mental effort in the Architecture } \\
\text { Department. Our number is not enough for this department." }\end{array}$ \\
\hline
\end{tabular}

The question of "What are the processes you want to change?"was answered by all department officers. According to the responses given by all department officers to this question, the increase in workload, the missing number of employees in departments, intertwined responsibilities in the inter-departmental and the unplanned processes are 
determined as common processes that need to change.

Table 6. What do you think about your duties and responsibilities?

\begin{tabular}{|l|l|l|}
\hline Position & Interviewee & Answer to the Question \\
\hline $\begin{array}{l}\text { Purchasing } \\
\text { Manager }\end{array}$ & $\mathrm{K} 3$ & $\begin{array}{l}\text { "As Purchasing Department employees, We have no job } \\
\text { descriptions, uncertainties prevail in the distribution of our } \\
\text { duties and responsibilities, and all things work together." } \\
\text { "Because I come from the institution, or maybe we're used to it } \\
\text { or it is what it should be, it has to go in a sequence." "There } \\
\text { must be a certain hierarchy in the organizational chart". }\end{array}$ \\
\hline $\begin{array}{l}\text { Accounting } \\
\text { Manager }\end{array}$ & K5 & $\begin{array}{l}\text { "In the department, we generally deal with business except our } \\
\text { own duties and responsibilities and I do not have to make a } \\
\text { contract agreement. "Preparing waybill/dispatch is not among } \\
\text { our duties. But from time to time, waybill/dispatch are prepared } \\
\text { by us. Nobody's job descriptions are clear. As a department, we } \\
\text { are dealing with off-duty jobs, which causes our workload to } \\
\text { increase. I can't teach our preliminary accountant anything } \\
\text { further. As a department, we do not run away from work, } \\
\text { however, we do not want to take jobs that are out of our } \\
\text { responsibility." }\end{array}$ \\
\hline $\begin{array}{l}\text { "As Operations Department, we take on the duties and } \\
\text { responsibilities of other departments in part." }\end{array}$ \\
\hline $\begin{array}{l}\text { Operations } \\
\text { Manager }\end{array}$ & E3 &
\end{tabular}

According to the answers given to the question of "What do you think about your duties and responsibilities?", it was seen that all department officers wanted a clear distinction in their duties and responsibilities. The most emphasized point in the responses given was the "workload". It can be said that all employees have problems in terms of workload. As a result, the lack of clarity in duties and responsibilities affects not only one department but all departments. Such a situation causes the formation of a conflict environment in general and prevents the corporate management approach.

Table 7. What are the problems you observe throughout the business?

\begin{tabular}{|l|l|l|}
\hline Position & Interviewee & Answer to the Question \\
\hline $\begin{array}{l}\text { Business } \\
\text { Development } \\
\text { Manager }\end{array}$ & $\mathrm{K} 2$ & $\begin{array}{l}\text { "This is not where it should be. It's about processes. It is due to the } \\
\text { inability to execute processes properly." "As the Business } \\
\text { Development Department, we adopt the brand. However, all these } \\
\text { problems negatively affect the management of processes and damage } \\
\text { the trust environment. With the weakening of the sense of belonging, } \\
\text { Ieven have thoughts about quitting the job." }\end{array}$ \\
\hline $\begin{array}{l}\text { Purchasing } \\
\text { Manager }\end{array}$ & $\mathrm{K} 3$ & $\begin{array}{l}\text { "We don't have job descriptions, uncertainty prevails in the } \\
\text { distribution of our duties and responsibilities, and all things work } \\
\text { together. "....But I said that sequence. At the point where it should } \\
\text { go in the form of that sequence, sometimes we can get blocked." }\end{array}$ \\
\hline
\end{tabular}




\begin{tabular}{|c|c|c|}
\hline $\begin{array}{l}\text { Help Desk } \\
\text { Personnel }\end{array}$ & K4 & $\begin{array}{l}\text { "There is also a little lack of communication. Maybe there's more of } \\
\text { a lack of communication between employees than between } \\
\text { management." }\end{array}$ \\
\hline $\begin{array}{l}\text { Accounting } \\
\text { Manager }\end{array}$ & K5 & $\begin{array}{l}\text { "We have a lot of principal circulation, senior management are } \\
\text { leading, communication between departments is very poor and we } \\
\text { have serious problems with communication. There is no clarity in } \\
\text { our duties and responsibilities as employees." }\end{array}$ \\
\hline $\begin{array}{l}\text { Chief } \\
\text { Accounting } \\
\text { Officer }\end{array}$ & E5 & $\begin{array}{l}\text { "While the departments fulfill their duties and responsibilities, the } \\
\text { intervention of the senior management at some points causes the } \\
\text { authority to be damaged and all the labor and effort to be wasted. } \\
\text { In order to prevent senior management from making sudden } \\
\text { decisions, management should withdraw itself on some issues." }\end{array}$ \\
\hline $\begin{array}{l}\text { Operations } \\
\text { Manager }\end{array}$ & E3 & $\begin{array}{l}\text { "There is an unnecessary gossip in the business, and work cannot be } \\
\text { followed in cases where communication between departments is } \\
\text { carried out by mail" }\end{array}$ \\
\hline Art Director & E4 & $\begin{array}{l}\text { "Ideas and thoughts are very important in this department. But we } \\
\text { work mechanically in this department. This type of work can lead to } \\
\text { a reduction in the quality of designs, creativity and productivity." }\end{array}$ \\
\hline $\begin{array}{l}\text { Deputy } \\
\text { Director } \\
\text { General }\end{array}$ & E1 & $\begin{array}{l}\text { "An important issue in the business is addressed by individuals who } \\
\text { have no solution partner or experience and these individuals are } \\
\text { included in the strategies.", "Responsibilities are given directly to } \\
\text { the employee without any prior preparation." }\end{array}$ \\
\hline $\begin{array}{l}\text { Project } \\
\text { Manager }\end{array}$ & K1 & $\begin{array}{l}\text { "There are conflicts of role and authority. And the existence of these } \\
\text { conflicts disrupts works". "Everyone who works here is very young, } \\
\text { and that's why they lack experience". "The fact that the employee } \\
\text { does not know where he is or is not able to use initiative prevents the } \\
\text { disclosure of skills in the business." }\end{array}$ \\
\hline
\end{tabular}

According to the answers given to the question of "What are the problems you observe throughout the business?", common problem areas observed throughout the business were identified. It is evaluated that the inability to carry out processes in a healthy and specific plan, problems in terms of authority and hierarchy, lack of clear duties and responsibilities, poor communication and coordination between departments are the common problems that spread throughout the business.

According to the answers to all these questions addressed to the department officers, lack of clarity in terms of authority and hierarchy, lack of job descriptions of department employees, employees' knowledge of their mandate and responsibility and increase in workload, role conflicts, unplanned and unprogrammed progress and lack of reporting system are the most emphasized issues in the interview. It is concluded that all of the information received from the department officers is mainly due to the lack of human resources practices, in other words, because the human resources processes cannot be carried out properly in the business. It can be said that the deficiencies in human resources practices and the resulting problems prevent the institutionalization of the business in question and thus the formation of a corporate governance approach. 


\section{Conclusion}

Establishing human resources practices appropriately and effectively allows employees to be perceived as a value and to run businesses within the system. Besides, it prepares the ground for institutionalization and corporate governance understanding. As a result, people are at the core of both institutionalization and corporate governance.

The qualitative data obtained from the research reveals deficiencies in the business's human resources practices. It can be said that such a situation is related to the absence of a human resources department in the business and the management of the business away from a good management understanding. The failure to execute human resources practices fully and effectively results in the absence of any written data in the business included in the study, the absence of professional managers in the business, or even the loss of these managers in a short time. On the other hand, the employees have difficulty making sure of their work they are conducting and remain reluctant to use initiative. However, poor communication does not bring employees together on a common ground, causing a conflict environment within the business. All these findings obtained in the business included in the study are closely related to formalization, professionalization, autonomy, culture, transparency and consistency known as institutionalization elements. The absence of such deficiencies in human resources practices or their inability to carry out these practices fully and effectively constitutes the biggest obstacle to the formation of institutionalization and that would damage institutionalization.

Another result from the study is on corporate governance. According to the findings of the sample, all the deficiencies in the field of human resources practices make it difficult for the business to be managed with the principles of transparency, fairness, accountability and responsibility known as corporate governance principles. The reason for this is thought that there is no infrastructure or insufficient infrastructure in the formation of corporate management, business owners try to manage the business away from a good management understanding and there are conflicts between business owners. Such a situation makes it almost impossible to manage the business with a corporate governance approach.

According to the responses and observations taken from the sample, the biggest obstacle to the formation of corporate governance understanding is the inability of the business to complete the institutionalization process due to deficiencies in human resources practices. According to all the findings obtained from the interviews, it was determined that there was no infrastructure for human resources practices in the mentioned business. As a matter of fact, the lack of human resources department in the business confirms that this infrastructure cannot be formed. As a result, it was determined that deficiencies in human resources practices prevent institutionalization within the enterprise and then prevent the formation of corporate governance understanding.

As a result of the recommendations developed for the business and employees, it is thought that what needs to be done in terms of both parties will bring about an understanding of corporate governance. To do this, businesses must first conduct business analysis. Along with the correct job analysis work, the basis of other human resources practices is formed. By 
means of job analysis, tasks and responsibilities are separated, workloads are eliminated and the work to be done by one department is prevented from being done by another department. Effective human resources practices strengthen the relations of employees with each other, ensure business peace within the business, create an environment of trust and lay the foundation of the corporate management approach in the business.

\section{References}

Anand, S. (2007). Essentials of corporate governance. Hoboken, N.J: John Wiley \& Sons, Inc. https://doi.org/10.1002/9781118385210

Armstrong, M. (1999). A handbook of human resource management practice. Londan: Kogan Page Publishers.

Athmen, B., \& Samia, B. (2017). The Importance of human resources in corporate governance. Mediterranean Journal of Social Sciences, 8(4-1), 161-164. https://doi.org/10.2478/mjss-2018-0086

Bandsuch, M., Pate, L., \& Thies, J. (2008). Rebuilding stakeholder trust in business: An examination of principle-centered leadership and organizational transparency in corporate governance. Business and Society Review, 113(1), 99-127. https://doi.org/10.1111/j.1467-8594.2008.00315.x

Barnes, L. B., \& Hershon, S. A. (1976). Transferring power in the family business. Harvard Business Review, 54(4), 105-114.

Beatty, R. W., Ewing, J. R., \& Tharp, C. G. (2003). HR's role in corporate governance: Present and prospective. Human Resource Management, 42(3), 257-269. https://doi.org/10.1002/hrm.10084

Belloc, F. (2012). Corporate governance and innovation: A survey. Journal of Economic Surveys, 26(5), 835-864. https://doi.org/10.1111/j.1467-6419.2011.00681.x

Bresnen, M. (2013). Advancing a 'new professionalism': professionalization, practice and institutionalization. Building Research \& Information, 41(6), 735-741. https://doi.org/10.1080/09613218.2013.843269

Brock, D. M. (2003). Autonomy of individuals and organizations: Towards a strategy research agenda. International Journal of Business and Economics, 2(1), 57-73.

Broom, L., \& Selznick, P. (1975). Sociology: A text with adapted readings. New York: Harper\& Row Publishers.

Bushman, R. M., Piotroski, J. D., \& Smith, A. J. (2004). What determines corporate transparency?. Journal of Accounting Research, 42(2), 207-252. https://doi.org/10.1111/j.1475-679X.2004.00136.x

Çolak, M. (2018). Çalışma kültürü. İzmir: Kitapana Yayınevi.

Colyvas, J. A., \& Powell, W. W. (2006). Roads to institutionalization: The remaking of boundaries between public and private science. Research in organizational behavior, 27, 305-353. https://doi.org/10.1016/S0191-3085(06)27008-4 


\section{Mll Macrothink}

International Journal of Human Resource Studies

ISSN 2162-3058 2020, Vol. 10, No. 3

Curtin, D., \& Meijer, A. J. (2006). Does transparency strengthen legitimacy?. Information Polity, 11(2), 109-122. https://doi.org/10.3233/IP-2006-0091

Denison, D. R. (1990). Corporate culture and organizational effectiveness. New York: John Wiley \& Sons.

Doğan, M. (2007). Kurumsal yönetim. Ankara: Siyasal Kitabevi.

Erkan, M. (2012). Türk ticaret kanunu'nda aile işletmelerinde kurumsallaşma ve iç denetim. Bursa: Ekin Basım Yayın Dağıtım.

Fisher, J. (2004). Social responsibility and ethics: Clarifying the concepts. Journal of Business Ethics, 52(4), 391-400. https://doi.org/10.1007/s10551-004-2545-y

Ganesh, S., \& McAllum, K. (2012). Volunteering and professionalization: Trends in tension?. Management Communication Quarterly, 26(1), 152-158. https://doi.org/10.1177/0893318911423762

Harris, O. J., \& Hartman, S. J. (2001). Organizational behaviour. Binghamton, NY: Best Business Books.

Hodge, B. J., Anthony, W. P., \& Gales, L. M. (2003). Organization theory: A strategic approach. Upper Saddle River - New Jersey: Prentice Hall.

Hrebiniak, L. G. (1976). Size and staff professionalization. Academy of Management Journal, 19(4), 662-669. https://doi.org/10.5465/255800

Huselid, M. A. (1995). The impact of human resource management practices on turnover, productivity, and corporate financial performance. Academy of Management Journal, 38(3), 635-672. https://doi.org/10.5465/256741

Ibrahim, H. I., \& Zulkafli, A. H. (2016). Corporate governance, HRM practices and organizational performance. Socio-Economic Problems and the State, 14(1), 30-40. $10.14254 / 2223-3822.2016 .14-1.4$

Kansikas, J. (2010). Understanding family dynasty: Nurturing the corporate identity across generations. International Journal of Business Science and Applied Management, 5(3), $31-42$.

Konzelmann, S. J., Conway, N., \& Wilkinson, F. (2007). Corporate governance and employment relations. Available at SSRN: https://ssrn.com/abstract=1930851. http://dx.doi.org/10.2139/ssrn.1930851

Konzelmann, S., Conway, N., Trenberth, L., \& Wilkinson, F. (2006). Corporate governance and human resource management. British Journal of Industrial Relations, 44(3), 541-567. https://doi.org/10.1111/j.1467-8543.2006.00512.x

Lane, C. (2003). Changes in corporate governance of German corporations: Convergence to the Anglo-American model?. Competition \& Change, 7(2-3), 79-100. https://doi.org/10.1080/1024529032000146678

Lawrence, T. B., Winn, M. I., \& Jennings, P. D. (2001). The temporal dynamics of institutionalization. Academy of Management Review, 26(4), 624-644. https://doi.org/10.5465/amr.2001.5393901 


\section{I Macrothink}

International Journal of Human Resource Studies

ISSN 2162-3058 2020, Vol. 10, No. 3

Leuthesser, L., \& Kohli, C. (1997). Corporate identity: The role of mission statements. Business Horizons, 40(3), 59-66. https://doi.org/10.1016/S0007-6813(97)90053-7

Martin, G., \& Gollan, P. J. (2012). Corporate governance and strategic human resources management in the UK financial services sector: the case of the RBS. The International Journal of Human Resource Management, 23(16), 3295-3314. https://doi.org/10.1080/09585192.2012.689159

Martin, G., Farndale, E., Paauwe, J., \& Stiles, P. G. (2016). Corporate governance and strategic human resource management: Four archetypes and proposals for a new approach to corporate sustainability. European Management Journal, 34(1), 22-35. https://doi.org/10.1016/j.emj.2016.01.002

Meyer, J. W., \& Rowan, B. (1977). Institutionalized organizations: Formal structure as myth and ceremony. American Journal of Sociology, 83(2), 340-363. https://doi.org/10.1086/226550

Mihalache, R. A., \& Albu, R. G. (2016). Organizational culture - A factor of potential positive influence on the collectivities of any organization. Bulletin of the Transilvania University of Brasov. Series V: Economic Sciences, 9(1), 149-156.

Monks, R. A. G., \& Minow, N. (2008). Corporate governance. United States: John Wiley \& Sons.

Nyambegera, S. M. (2017). Corporate governance and human resource management policy practice nexus: a case for stakeholder perspective in Kenya's public limited companies. International Journal of Business and Management Invention, 6(12), 21-30.

Olins, W. (1990). Corporate identity: Making business strategy visible through design. Boston: Harvard Business School Press.

Pauly, L. W., \& Reich, S. (1997). National structures and multinational corporate behavior: Enduring differences in the age of globalization. International Organization, 51(1), 1-30. https://doi.org/10.1162/002081897550285

Selznick, P. (1957). Leadership in administration. New York: Harper \& Row.

Shearer, T. (2002). Ethics and accountability: From the for-itself to the for-the-other. Accounting, Organizations and Society, 27(6), 541-573. https://doi.org/10.1016/S0361-3682(01)00036-8

Supangco, V. T. (2006). HR involvement in corporate governance. Philippine Management Review, 13, 101-116.

Tawney, G. A. (1907). Constitutive consistency. The Philosophical Review, 16(1), 21-39. https://doi.org/10.2307/2177576

Tricker, B. (2009). Corporate governance: Principles, policies, and practices. New York: Oxford University Press.

Wallace, J. E. (1995). Organizational and professional commitment in professional and nonprofessional organizations. Administrative Science Quarterly, 40(2), 228-255. 
https://doi.org/10.2307/2393637

\section{Copyright Disclaimer}

Copyright for this article is retained by the author(s), with first publication rights granted to the journal.

This is an open-access article distributed under the terms and conditions of the Creative Commons Attribution license (http://creativecommons.org/licenses/by/4.0/). 